Dr SLOBODAN SELINIĆ, viši naučni saradnik

Institut za noviju istoriju Srbije

Beograd, Republika Srbija

slobodanselinic@gmail.com

originalan naučni rad

UDK: 327.55:316.72(497.1)"195/197"

primljeno: 19 . avgust 2018.

821:061.2(497.1)"195/197"

prihvaćeno: 21 . novembar 2018.

https://doi.org/10.29362/ist20veka.2019.1.sel.175-192

\title{
SAVEZ KNJIŽEVNIKA JUGOSLAVIJE I NESVRSTANE ZEMLJE OD KRAJA PEDESETIH DO POČETKA OSAMDESETIH GODINA 20. VEKA*
}

APSTRAKT: Književna saradnja Jugoslavije i nesvrstanih zemalja nije bila na nivou značaja tih država za spoljnu politiku Jugoslavije. U odnosu na političke veze ili odnose u drugim sferama života, poput nauke, ostvarivana je kasnije i slabijim intenzitetom. I pored toga, u literarnim vezama sa pojedinim zemljama, kao što su Indija, Egipat ili Alžir, uspostavljena je saradnja u vidu poseta književnika i prevođenja književnih dela.

KLJUČNE REČI: Jugoslavija, nesvrstane zemlje, književnost, Indija, Egipat, Alžir

Nesvrstana spoljna politika činila je jednu od osnovnih odlika socijalističke Jugoslavije. ${ }^{1}$ Književna saradnja Jugoslavije sa nesvrstanim zemljama

\footnotetext{
* Rad je deo projekta Srbi i Srbija u jugoslovenskom i međunarodnom kontekstu: unutrašnji razvitak i položaj u evropskoj/svetskoj zajednici (47027) koji finansira Ministarstvo prosvete, nauke i tehnološkog razvoja Republike Srbije.

${ }^{1}$ Olivera Bogetić i Dragan Bogetić, Nastanak i razvoj pokreta nesvrstanosti (Beograd: Export press, 1981); Dragan Bogetić i Ljubodrag Dimić, Beogradska konferencija nesvrstanih zemalja 1-6. septembra 1961: prilog istoriji Trećeg sveta (Beograd: Zavod za udžbenike, 2013); Jovan Čavoški i Aleksandar Životić, "On the Road to Belgrade: Yugoslavia, Third World Neutrals and the Evolution of Global Non-Alignment, 1954-1961", Journal of Cold War Studies, vol. 18, no. 4, (2016), 77-97; Јован Чавошки, „Рука пружена преко света: југословенска подршка Бурми у борби против спољне агресије 1952-1954“, Токови историје, 2, (2018), 143-176; Драгомир Бонџић, Мисао без пасоша: међународна сарадња Београдског универзитета 1945-1960 (Београд: Институт за савремену историју, 2011); Jovan Čavoški, "Arming Nonalignment: Yugoslavia's Relations with Burma and the Cold War in Asia, 1950-1955", CWIHP Working Paper, no. 61. Washington, DC: Woodrow Wilson Center, 2010; Dragomir Bondžić, „Stipendisti iz Indije i Burme u Jugoslaviji 1951-1955“, Spoljna politika Jugoslavije 1950-1961, Zbornik radova, ur. Slobodan Selinić (Beograd: INIS, 2008), 558-570; Dragomir Bondžić, „Školovanje studenata iz zemalja u razvoju kao deo spoljne politike Jugoslavije 19501961“, Annales. Anali za istrske in mediteranske študije. Series Historia et Sociologia, 24, (2014), 4, (Koper 2014), 637-648; Југословенско-алжсирски односи 1956-1979, приредили
} 
bila je ispod važnosti ovih zemalja za spoljnu politiku Jugoslavije. Politički i ekonomski odnosi i saradnja u oblasti nauke su bili mnogo razvijeniji od saradnje pisaca, pa je vremenom Savez književnika Jugoslavije došao u situaciju da je prihvatao samo onu saradnju koju je morao prema međudržavnim kulturnim konvencijama. Saradnja sa nesvrstanima je bila ostvarena kasno, slaba po intenzitetu, neredovna i nedovoljna iz više razloga. U članku ćemo se prevashodno posvetiti saradnji koju je sa nesvrstanima ostvario Savez književnika Jugoslavije od kraja pedesetih do početka osamdesetih godina 20. veka.

Za Jugoslaviju je veliki problem predstavljala udaljenost nesvrstanih zemalja i teškoće oko pronalaženja sredstava za finansiranje putovanja njenih pisaca. To je ionako krhku saradnju sa nesvrstanima dodatno ugrozilo, posebno početkom osamdesetih, pa se moglo putovati samo tamo gde je JAT leteo. Tako je međunarodna saradnja sa udaljenim zemljama zavisila od finansijskih sredstava i JAT-ovog reda letenja. Saradnji nije doprinosilo ni to što vodeći pisci nesvrstanih zemalja nisu stavljali Jugoslaviju na vrh liste svojih prioriteta, jer su prevashodno želeli da svoja dela objave na vodećim svetskim jezicima ili su i dalje bili vezani za bivše kolonijalne metropole. ${ }^{2} \mathrm{Ni}$ jugoslovenski savez pisaca nije uvek koristio sve mogućnosti za saradnju sa nesvrstanim zemljama. Nepoznavanje prilika u nesvrstanim zemljama i nepripremljenost za saradnju bila je široko rasprostranjena pojava među jugoslovenskim piscima. Na sednici Komisije za kulturne veze sa inostranstvom 25. aprila 1960. Aleksandar Vučo je govorio o neprijatnostima koje su se dešavale kada su jugoslovenske delegacije putovale $\mathrm{u}$ afričke $\mathrm{i}$ azijske zemlje, ne znajući ništa o literaturi tih zemalja. Takva delegacija u UAR nije bila upoznata da je u Kairu izlazio časopis na francuskom jeziku i da su Arapi očekivali da im Jugosloveni donesu tekstove na francuskom jeziku koje bi odmah štampali. ${ }^{3}$ Ovakvu inertnost jugoslovenskih pisaca i nespremnost da ulože napor kako bi književnom saradnjom pratili napredak u političkim odnosima sa nesvrstanima Ivan Ivanji je 1980. označio kao osnovni uzrok što Savez književnika Jugoslavije nije u dovoljnoj meri iskoristio ugled nesvrstane i samoupravne Jugoslavije u svetu radi uspostavljanja potpunijih književnih veza. ${ }^{4}$

Brojni primeri nespremnosti ili nemogućnosti jugoslovenskog saveza pisaca da književnu saradnju sa nesvrstanima podigne na viši nivo nisu značili da među piscima nije postojala svest o važnosti te saradnje niti da nije bilo brojnih pokušaja i uspeha.

Миладин Милошевић и Нада Пантелић (Београд: Архив Југославије, 2014); Љубодраг Димић, Александар Раковић и Миладин Милошевић, Југославија - Индонезија 19451967: истражсивања и документа (Београд: Архив Југославије, 2014).

2 Arhiv Jugoslavije (AJ), fond 498, Savez književnika Jugoslavije, fascikla 61, Sastanak SKJ o međunarodnoj saradnji, 25. 1. 1984.

${ }^{3}$ AJ, 498-33, Sastanak komisije za veze sa inostranstvom, 25. 4. 1960.

${ }^{4}$ AJ, 498-59, Br. 598. 
Specifičnost odnosa sa nesvrstanima sublimirao je Drago Vučinić, sekretar Komisije za kulturne veze sa inostranstvom 1962. godine: „Onaj ko bude tamo išao mora biti i fizički spreman za ostvarenje zadatka: ako on bude tamo patio od srca ili ne bude mogao podneti vrućinu - gotovo je s njegovom ulogom". Istovremeno, pisci koji su odlazili u te zemlje su trebali da budu ,generalni informatori" tih zemalja o prilikama u Jugoslaviji i Jugoslavije o prilikama u tim zemljama. ${ }^{5}$

Već u drugoj polovini pedesetih godina jugoslovenski savez pisaca je pokazivao interesovanje za veze sa afričkim piscima. To se videlo i po tome što je na prvi kongres „,rnačkih književnika i umetnika“ u Parizu septembra 1956. poslat jugoslovenski posmatrač i to je bio prof. Petar Guberina iz Zagreba, koji je imao dosta ličnih poznanstava među „crnačkim književnicima i umetnicima“ i dobro je poznavao crnačku književnost. ${ }^{6}$ Jugoslavija je želela da nastavi kontakte sa ovom organizacijom, pa je i drugom kongresu krajem marta i početkom aprila 1959. u Rimu prisustvovao Guberina. Savez književnika je za takvu politiku imao podršku državnih organa, tako da je odlazak Guberine u Rim podržao i predsednik Odbora za spoljne poslove Savezne narodne skupštine Aleš Bebler. ${ }^{7}$ Već prvi kongres je okupio crnce sa svih kontinenata, a na drugom je sastav bio još reprezentativniji. Prisustvovala je delegacija iz Gane, koje nije bilo na prvom. Američki crnci su imali delegaciju od 12 osoba. Bili su i predstavnici Kameruna, Belgijskog Konga, Čada, Gvineje, Ruande, Rodezije, Južne Afrike, predstavnik alžirskog pokreta za oslobođenje Franc Fanon, delegacije Etiopije i Sudana, koje su predstavljali njihovi ambasadori u Rimu. ${ }^{8}$ Jugoslavija je vrlo pomno pratila oba kongresa, posebno drugi. Doživela ih je kao rezultat borbe naroda za oslobođenje od imperijalizma i kolonijalizma, u kojoj je većina intelektualaca tih zemalja učestvovala. ${ }^{9}$

Dobar pokazatelj jugoslovenskih književnih pozicija u nesvrstanom svetu bio je odnos sa Konferencijom afro-azijskih pisaca. Na ovim skupovima Jugoslavija je mogla da sagleda svoj književni uticaj u nesvrstanom svetu i shvati da je sovjetski uticaj na rad ove organizacije bio daleko veći. Na ove konferencije Jugoslavija je slala delegate kao posmatrače, ali bez ozbiljnijeg upliva na nesvrstane pisce.

Na takav skup u Kairu februara 1962. Tanasije Mladenović i Jordan Leov, kao predstavnici Jugoslavije, uspeli su da uđu sa zakašnjenjem i to ilegalno. Suočili su se sa time da je Egipćanima jugoslovensko prisustvo predstavljalo politički problem, jer su prvenstvo dali stavu kineskih predstavnika da će napustiti konferenciju ako se pojave jugoslovenski pisci. Na skup su zato ušli „na mala vrata“, koristeći novinarske akreditacije koje im je nabavila jugoslovenska ambasada. ${ }^{10}$

\footnotetext{
5 AJ, 498-33, Br. 1549.

6 AJ, 498-32.

7 AJ, 498-25, Br. 162.

${ }^{8}$ AJ, 498-32.

9 AJ, 498-32.

${ }^{10}$ AJ, 498-33, Komisiji za kulturne veze sa inostranstvom.
} 
Do druge polovine sedamdesetih, sa saznanjem kako se odvijao rad Izvršnog komiteta organizacije afroazijskih pisaca na sastancima u Moskvi, Taškentu, Alma Ati, Bejrutu, Nju Delhiju i Bagdadu, jugoslovenskim piscima je bilo lako da zaključe da je SSSR ostvario uticaj u ovoj organizaciji. Blagoje Ivanov je na sastanku u Bagdadu 1976. zapazio da se veliki sovjetski uticaj na ovu organizaciju očitovao i u materijalnoj pomoći, davanju stipendija, putovanjima, prevođenju. ${ }^{11}$ Kada su zahladili odnosi Moskve i Kaira 1976, Predrag Matvejević je na Internacionalnoj sesiji mladih pisaca Azije i Afrike, održanoj u Taškentu od 26. septembra do 3. oktobra 1976, svedočio o visokom stepenu podeljenosti te organizacije između Moskve i Kaira. Njeni članovi su se kolebali između koncepta nesvrstanosti i pripadnosti sovjetskom konceptu, pa je u takvim uslovima, zahvaljujući sovjetskom delovanju, Matvejević osećao podozrenje prema sebi kao jugoslovenskom predstavniku. Njegovo izlaganje, koje je objavljeno u biltenu sa ovog skupa, bilo je „rezimirano“ na taj način da je svedeno na nekoliko „toliko uopćenih fraza da se ne da razabrati o čemu sam ja zapravo govorio“. ${ }^{12}$

Iako je bila svesna značaja ove organizacije, Jugoslavija je na konferenciju afro-azijskih pisaca u Taškentu oktobra 1978. poslala zadarskog pisca Tomislava Marijana Bilosnića polupripremljenog za ono što ga očekuje na skupu takve vrste. Njegovo učešće na konferenciji su obeležili zainteresovanost pisaca nesvrstanih zemalja za jugoslovenski stav, podozrenja sovjetskih domaćina prema kontaktima pisaca Azije i Afrike sa njim i posledice jugoslovenske inertnosti prema piscima nesvrstanih zemalja, što je bilo vidljivo iz razočaranosti delegacije Etiopije zbog odnosa jugoslovenskog saveza pisaca prema uzajamnoj saradnji. ${ }^{13}$

$\mathrm{Na}$ 12. kongresu arapskih pisaca u Damasku od 24. do 30. novembra 1979. Jugoslaviju je predstavljao Milisav Savić. Kongres je okupio pisce iz svih arapskih zemalja. Kao posmatrači su prisustvovali pisci SSSR-a, Istočne Nemačke, Poljske, Rumunije i Jugoslavije. Usvojen je dokument kojim je istaknuta uloga pisca i pisane reči u zajedničkim ciljevima arapskog naroda. Pisci su se obavezali da rade na učvršćivanju jedinstva arapskih naroda i pomažu borbu protiv cionizma i imperijalizma. Oštro je osuđena politika egipatske vlade. Savić je iskoristio priliku za neformalne kontakte sa sirijskim i ostalim arapskim piscima, uočavajući veliko interesovanje za Jugoslaviju i njenu književnost, ali i da su u tom delu sveta bili slabo upoznati sa jugoslovenskom književnošću, uprkos velikog ugleda zemlje zbog nesvrstane politike. U Jugoslaviju se vratio bogatiji za oko stotinu najnovijih izdanja koje je dobio na poklon i koje je nameravao da ustupi Darku Tanaskoviću i Radetu Božoviću, prevodiocima sa arapskog. ${ }^{14}$

Kada su već formalne veze sa književnicima nesvrstanih zemalja bile slabe, Jugosloveni su iskoristili Oktobarski susret pisaca 1981. za održavanje neformalnog susreta pisaca nesvrstanih zemalja, koji su u Beogradu učestvovali

\footnotetext{
${ }^{11}$ AJ, 498-42, Blagoje Ivanov, Izveštaj iz Bagdada.

${ }^{12}$ AJ, 498-42, Izveštaj Predraga Matvejevića.

${ }^{13}$ AJ, 498-59, Br. 328.

14 AJ, 498-59, Izveštaj s puta 1977-1979, Izveštaj o učešću na XII kongresu arapskih pisaca u Damasku.
} 
na Oktobarskom susretu pisaca. Susret je 16. oktobra 1981. upriličen povodom dve decenije od Beogradske konferencije. Učestvovalo je 13 pisaca iz osam zemalja (Nigerija, Indija, Kuba, Brazil, Gvineja itd.), Duško Roksandić, Ivan Ivanji i Tibor Varadi (Jugoslavija). Sastankom je rukovodio Roksandić, koji je održao uvodno izlaganje. Konstatovano je da se pisci iz nesvrstanih zemalja dovoljno ne poznaju i da njihova udruženja ne sarađuju dovoljno, iako su šefovi država i vlada na sastanku u Havani 1979. preporučili takvu saradnju za koju je, uz to, postojala ,povoljna politička i društvena klima“. Predloženo je da se ta pitanja razmotre u nacionalnim savezima pisaca $i$ da jugoslovenski savez bude adresa na koju će stizati sve sugestije. Nagoveštena je i mogućnost održavanja šireg skupa pisaca nesvrstanih država. U tom cilju je predložen odbor u koji su ušli predstavnici Kube, Indije, Iraka, Nigerije i Jugoslavije. Učesnici razgovora su 17. i 18. oktobra bili gosti grada Kruševca i izdavačke kuće „Bagdala“. Obišli su grad, fabriku „Merima“ i podrume „Navipa“. Za Kruševljane su priredili „veoma uspelo i lepo posećeno“ književno veče. Domaćini gostima su bili Grozdana Olujić i Ivan Gađanski, a prevodilac Mila Ćirković. ${ }^{15}$

Jugoslovenski savez književnika se više uključio u zagovaranje politike nesvrstanih na međunarodnom kongresu književnika „Interlit 82 “ koji je održan u Kelnu od 18. do 25. juna 1982. na temu „Savremeni književnici i njihov doprinos miru - granice i mogućnosti“. Jugoslaviju su zastupali Ivan Ivanji, Boško Petrović i Andrej Hieng. Na skupu 300 pisaca iz 48 zemalja Ivan Ivanji je inicirao diskusiju kojom je oboren predlog zajedničke rezolucije koju je izradio komitet sastavljen od predstavnika obe Nemačke, SSSR-a, Bugarske, SAD, Indije i Kameruna. Ivanji je prvom tekstu zamerio da je suviše evrocentričan i istakao u prvi plan zahteve koji su više bili u skladu sa politikom nesvrstanih zemalja. Zato je tražio da se umesto opasnosti od nuklearnog oružja insistira na opasnostima koje su po mir u svetu imali glad, siromaštvo, nepravda, rasizam i aparthejd. Novi tekst je uvažio ove primedbe i apelovao je na borbu protiv diskriminacije svake vrste, ističući potrebu detanta. ${ }^{16}$

$$
* * *
$$

U bilateralnim književnim odnosima Jugoslavije sa nesvrstanim zemljama nije bilo kontinuiteta, ali kontakata i uspeha jeste. U uspostavljanju saradnje sa pojedinim zemljama kasnilo se za političkom saradnjom, a u intenzitetu odnosa se zaostajalo za političkim, ekonomskim i naučnim vezama. Iznećemo više detalja o saradnji sa pojedinim zemljama, gde su rezultati bili opipljiviji ili gde izvori omogućavaju pouzdane zaključke.

Konkretni oblici saradnje književnika Jugoslavije i Alžira su zaživeli tek sedamdesetih godina i zaostajali su za saradnjom u drugim oblastima, poput

\footnotetext{
15 AJ, 498-54, Nesvrstani, 1981, 1982; Isto, Dokumentacija sa skupa pisaca iz nesvrstanih zemalja.

${ }^{16}$ AJ, 498-59, Izveštaj o učešću delegacije Saveza književnika Jugoslavije.
} 
nauke. ${ }^{17}$ Tih godina su Alžirci počeli da dolaze na književne manifestacije u Jugoslaviji. Na Zagrebačkim književnim razgovorima učestvovali su 1973. i 1974, Sarajevskim danima poezije 1976. i 1977, Susretima pisaca na Bledu 1977. i 1981, na Struškim večerima poezije 1974. i 1977, a na Oktobarskim susretima pisaca u Beogradu 1981. U Strugi je 1977. bila četvoročlana delegacija alžirskih pisaca, jer je posebno veče bilo posvećeno alžirskoj poeziji i tim povodom je na makedonskom jeziku objavljena knjiga alžirske poezije. Saradnja na prevodilačkom planu je bila jednostrana. Od sredine sedamdesetih do sredine osamdesetih u Jugoslaviji je objavljeno devet knjiga ili antologija u kojima se nalazila alžirska poezija, a u Alžiru nije objavljena nijedna knjiga ili zbirka jugoslovenske poezije i proze. ${ }^{18}$

Za nezadovoljavajuće prisustvo jugoslovenske kulture u Alžiru najviše su bili odgovorni sami Jugosloveni. Od konferencije nesvrstanih u Beogradu 1961, narednih dvadesetak godina su bile retke jugoslovenske ličnosti koje su duže vreme boravile u toj zemlji, a da su imale dodira sa književnošću. Dramatično zaostajanje književne saradnje Jugoslavije i Alžira za političkim odnosima najbolje se videlo na policama velike partijske knjižare u gradu Alžiru. Bila je „dobro uređena i još bolje vođena“, u njoj su postojala dela iz gotovo svih zemalja sa kojima je Alžir imao dobre odnose, osim Jugoslavije. ${ }^{19}$

Veoma značajan iskorak u saradnji sa Alžirom bila je poseta Ćamila Sijarića, Mire Alečković i Atanasa Vangelova, koji su na osnovu programa prosvetno-kulturne saradnje posetili Alžir u jesen $1977 .{ }^{20}$ Izbor Sijarića, koji je znao arapski jezik, pokazuje da se vodilo računa o prilagođavanju zemlji u koju se putuje. Alžirci su ovoj poseti dali širi kulturni, ali i politički i nacionalni značaj. Bilo im je stalo do toga da naglase svoju borbu za nezavisnost i predstave Jugoslovenima napore na kulturnom uzdizanju svoje zemlje. Zato su gosti iz Jugoslavije često imali razgovore u predstavništvima FLN, sa bivšim rukovodiocima pokreta otpora, piscima, direktorima škola, lekarima, apotekarima, direktorima domova kulture, koji su iskazivali mnogo simpatija za jugoslovensku borbu i samoupravljanje i naglašavali da im je Jugoslavija uzor. Jugosloveni su konstatovali da su bili primljeni „više nego srdačno i prijateljski“, tako da je poseta bila „koliko kulturna toliko propagandno-politička“. „Od jutra do mraka su nas negde vodili, nešto nam pokazivali, organizovali sastanke sa piscima, političarima, ljudima iz kulture, sa televizije i štampe, muzeja i upoznali nas sa kulturnim trenutkom savremenog Alžira“ - zapisala je posle povratka Mira Alečković. Jugoslovenski pisci su odgovarali na brojna pitanja domaćina o oslobodilačkoj borbi, književnosti, kulturi i tadašnjem „trenutku samoupravlja-

17 Југословенско-алжсиски односи 1956-1979, приредили Миладин Милошевић и Нада Пантелић, (Београд: Архив Југославије, 2014); Драгомир Бонџић, „Студенти из Алжира у Југославији 1958-1965“, Југославија - Алжир, Зборник радова са научне конференције, Алжир, 27. јануар 2013, главни и одговорни уредник Миладин Милошевић (Београд: Архив Југославије, 2013), 141-162.

${ }^{18}$ AJ, 498-54, Alžir.

${ }^{19}$ AJ, 498-54, Husein Tahniščić, Sarajevo, 25. 9. 1982.

${ }^{20}$ AJ, 498-57, Alžir. 
nja“. Svesni političke važnosti svoje posete, ali i osetljivosti političkih tema, morali su da se konsultuju sa svojom ambasadom kako bi odgovorili na pitanja o stavu Jugoslavije prema frontu Polisario, koje im je često postavljano. Da su jugoslovenski pisci bili uvereni kako je njihova misija daleko šira od književne saradnje, ali i da su se pred Jugoslavijom pojavljivali novi i nepoznati prostori, pokazuje zapažanje Mire Alečković da „se pred nama otkrio jedan novi svet“", pa su oni i jugoslovenski savez ,u kulturnom svetu Alžira otškrinuli još jedno malo prozorče za širu saradnju. A možda smo otvorili i prozor“. Ove reči su svedočanstvo i o skromnosti dotadašnjih veza.

Želja afričkih domaćina je bila da gostima pokažu istorijsko i kulturno bogatstvo novooslobođene zemlje i velike napore na daljem kulturnom uzdizanju. Osamsto kilometara koje su u samo jednom danu prešli po Sahari ubedilo je jugoslovenske pisce da je domaćinima najvažnije da ih upoznaju sa svojom zemljom. Upoznali su „tako reći dušu Sahare“, razgovarali sa seljacima, radnicima i intelektualcima koji su ih obasipali pitanjima o Jugoslaviji. Alžirci su na svakom koraku želeli da pokažu Jugoslovenima svoj kulturni napredak. U jednom mestu su im pokazali veličanstveni dom kulture, u kome je tada gostovao Lenjingradski balet. Posetili su muzeje i Likovnu akademiju u Alžiru, grad Tipazi (,,to je čitav grad-muzej na otvorenom nebu“), rimske ruševine Kartagine, Kleopatrinu grobnicu i usput se zaustavljali po selima u kojim je izrađivana grnčarija. Jugoslovenski književnici su alžirsku kulturu spoznavali i gledajući alžirske filmove i obilaskom filmskog preduzeća. Prvi dodiri sa alžirskim podnebljem su ostavili veliki utisak na Miru Alečković, pa su njeni opisi puni detalja, poput onih o jednom plemenu u Sahari u kojoj živi ,,jedan od drevnih naroda Afrike za koga se smatra da je poreklom s Atlantide ili po legendama sa drugih planeta. To su visoki, ne mnogo crni ljudi često plavih očiju i ruse kose Kabiljci. Njima su srodni još Berberi u centru Sahare“. Utisak koji je prostranstvo Alžira ostavilo na jugoslovenske pisce vidljiv je i iz opaske da je samo jedna vilaja koju su obišli bila čak sedam puta veća od Jugoslavije. Uski književni kontakti su bili u drugom planu. Jugoslovenski pisci su razgovarali i sa profesorima slavističke i orijentalističke katedre i prisustvovali predavanju u Savezu književnika Alžira o arabizaciji koja je bila u toku. ${ }^{21}$

Još jedan važan doprinos upoznavanju književnika Jugoslavije i Alžira dao je Husein Tahmiščić koji je doputovao u Alžir 6. septembra 1982. Ostao je dve sedmice kao gost Radio-televizije Alžir i svojevrsni izaslanik Predsedništva Saveza književnika Jugoslavije, koje ga je ovlastilo da ostvari kontakt sa Unijom alžirskih književnika i sa njenim predstavnicima razgovara o saradnji. Tahmiščić je potvrđivao utiske kolega koji su ranije boravili u Alžiru - u zemlji je postojao ,istinski interes za sve što Jugoslaviju čini socijalističkom, nesvrstanom i slobodnom zajednicom naroda i narodnosti“". On se trudio da pronikne u književne i izdavačke prilike u Alžiru i u njima pronađe mesto za proboj jugoslovenskih ostvarenja. Iz toga je proistekao zaključak: „Alžir ima svoj put raz-

${ }^{21}$ AJ, 498-42, Izveštaj Mire Alečković iz Alžira. 
voja, poleta i preobražaja, svoje teškoće i protuslovlja, a naša je obaveza da ga shvatimo, da ga podržimo i prihvatimo“. ${ }^{22}$

Do početka šezdesetih godina jugoslovenske veze sa kulturnim radnicima UAR (Egipta) bile su pojedinačne. U UAR je 1956. bila jugoslovenska delegacija koju su činili Skender Kulenović, Vladimir Borko i Ivan Dončević. Nijedno jugoslovensko delo nije bilo prevedeno na arapski, a u Jugoslaviji su bila objavljena klasična dela arapske literature i savremeni pisac Tawfiq Al Hakim. ${ }^{23}$ Plan međudržavne kulturne saradnje od 22. decembra 1958. predviđao je razmenu samo trojice pisaca i publicista. ${ }^{24}$ Tanane veze su nastavljene prijemom koji je u čast delegacije kulturnih radnika iz UAR priređen 19. avgusta 1959. u Klubu književnika, na kome su od pisaca bili Stevan Jakovljević, Oto Bihalji, Vasko Popa i drugi. ${ }^{25}$ Od 26. novembra do 12. decembra 1959. u UAR je boravila jugoslovenska delegacija u sastavu Skender Kulenović, Ivan Dončević i Vladimir Bartol. ${ }^{26}$

Odlazak Tanasija Mladenovića i Jordana Leova u UAR 12. februara 1962. na konferenciju pisaca arapskih zemalja bio je krupniji korak u pravcu redovne razmene Saveza književnika Jugoslavije i književnih organizacija UAR. O budućoj saradnji razgovarano je u njihovom prisustvu na sastanku Visokog saveza za književnost, umetnost i kulturu. Razmenjeni su pogledi o razmeni pisaca, časopisa, urednika, listova i materijala. Konstatovano je da je pitanje prevodilaca najosetljivije, jer nije bilo onih koji su znali arapski i jugoslovenske jezike, pa je zaključeno da se dve književnosti moraju upoznavati pomoću prevoda sa engleskog i francuskog jezika. Sa egipatskim kolegama su dugo razgovarali u Klubu pisaca, posetili su redakcije listova i časopisa ( $\mathrm{Al}$ Ahram) i imali niz pojedinačnih susreta sa piscima. Poseta je ocenjena u Jugoslaviji kao ,temelj za jednu perspektivnu saradnju“ ${ }^{27}$

Tamo gde je stala ova delegacija trebalo je da nastavi sledeća, to jest da sa preliminarnih dogovora pređe na ugovaranje konkretne saradnje. Jugoslavija je u tu delegaciju odredila Miru Mihelič Pucovu, autorku više romana i drama, koja je prevodila sa anglosaksonske književnosti i Tomislava Ladana, mladog kritičara, prevodioca i književnika. Ovakav izbor je naišao na negodovanje u Kairu, pa je ambasada Jugoslavije 13. januara 1963. upozorila da su Egipćani bili iznenađeni ,što šaljemo delegaciju mladih, malo poznatih i bez iskustva književnika“. Ambasada je predložila da sastav delegacije bude izmenjen u skladu sa egipatskom primedbom. Ministarstvo inostranih poslova je taj predlog odbilo i stalo je iza stručnosti jugoslovenskih pisaca. ${ }^{28}$

\footnotetext{
${ }^{22}$ AJ, 498-54, Husein Tahmiščić, Sarajevo, 25. 9. 1982.

${ }^{23}$ AJ, 498-32, 1961, Prepiska u vezi ostvarivanja međunarodne saradnje.

${ }^{24}$ Diplomatski arhiv Ministarstva spoljnih poslova Srbije (DA MSP), Politička arhiva (PA), 1959, UAR, f. 133, d. 2.

${ }^{25}$ AJ, 498-36, 1959-1963.

${ }^{26}$ AJ, 498-32, 1962, Prepiska u vezi ostvarivanja međunarodne saradnje, 22. 6. 1962.

${ }^{27}$ AJ, 498-36, 1959-1963; AJ, 498-14, XXIII plenum; AJ, 498-32, 1962, Prepiska u vezi ostvarivanja međunarodne saradnje, 715.

${ }^{28}$ DA MSP, PA, 1963, UAR, f. 137, d. 12, 430936.
} 
Poseta Mire Mihelič i Tomislava Ladana Egiptu od 18. januara do 6. februara 1963. dala je nagoveštaje ozbiljnije književne saradnje, ali se po pitanju realizacije glavnog cilja (sklapanje konkretnih aranžmana književne saradnje) nije odmaklo dalje od kurtoazne komunikacije. Najveći stručni uspeh bio je dogovor da se objave antologije egipatske i jugoslovenske poezije i proze. Obilaskom Kaira, Aleksandrije, Ismailije, Port Saida, Luksora i Asuana, posetom muzeju staroegipatske, koptske i islamske kulture, najreprezentativnijim industrijskim objektima, bojadisaonici platna blizu Aleksandrije, fabrici veštačkog đubriva u Asuanu i čuvenoj asuanskoj brani i električnoj centrali, Jugosloveni su se upoznali sa bogatom prošlošću ovog prostora, ali i nastojanjima da postane razvijeno društvo. Interesovanje za njih je bilo veliko. Davali su intervjue za kairske listove i dva puta se službeno sastali sa egipatskim piscima. U Klubu Jugoslovena u Kairu Mira Mihelič je govorila o književnoj situaciju u Sloveniji, a Ladan o „sadašnjim tokovima u srpskoj i hrvatskoj književnosti““. ${ }^{29}$

Jugoslovenska i egipatska diplomatija su nastavile da podstiču književnu saradnju. Tokom 1965. Ambasada u Kairu i generalni sekretar Visokog saveta za umetnost dr Jonssef El Sebahi ugovarali su razmenu pisaca, saradnju časopisa, prevođenje jugoslovenskih pisaca na arapski jezik i objavljivanje u Egiptu. Ambasada je Sebahiju dostavila na engleskom jeziku dela Cirila Kosmača, Kaleba, Krleže (Povratak Filipa Latinovića), Andrića (Travnička hronika), Pesmu Daviča i Antologiju jugoslovenske savremene poezije Zorana Mišića. ${ }^{30}$

Saradnja dva saveza pisaca je formalizovana ugovorom o saradnji Saveza književnika Jugoslavije i Unije egipatskih pisaca, koji je potpisan 1. juna 1973. u Beogradu. Ugovor je predviđao dolazak Egipćana na Struške večeri poezije, na Oktobarski susret pisaca, književne susrete u Sarajevu i Piranu, na Zagrebačke književne razgovore, kao i odlazak Jugoslovena u Egipat u ukupnom trajanju od 40 dana. ${ }^{31}$ Kratkotrajna poseta Fahri Kaje i Predraga Matvejevića Egiptu od 2. do 10. marta 1976. nije mogla da posebno unapredi književnu saradnju dve države, ali su je Jugosloveni iskoristili da saradnji udahnu nove impulse. Matvejević je egipatskim piscima održao predavanje o posleratnom razvoju jugoslovenske književnosti. U redakciji Al Ahrama su susreli poznatog arapskog pisca Hakima. Osim u Kairu, bili su u Aleksandriji, Port Saidu i obišli istorijska mesta i kulturne znamenitosti (piramide, Memfis, Sahara). ${ }^{32}$

I književni odnosi sa Burmom su upadljivo zaostajali sa političkim. Svodeći rezultate posleratne saradnje, savetnik ambasade u Burmi Milutin Rogić je 18. februara 1975. zapisao da je u prve tri decenije posle rata prisustvo jugoslovenskih knjiga u Burmi bilo skoro nikakvo. Do 1975. bile su prevedene i objavljene samo četiri jugoslovenske knjige i to političko-informativnog sadržaja, pa i one od 1954. do 1961. Tek 1974, na zauzimanje ambasade u Burmi,

\footnotetext{
${ }^{29}$ AJ, 498-33, 1962, 1963, 1964, 1966, 1968, Izveštaji, Putni izveštaj.

${ }^{30} \mathrm{AJ}, 498-29,628 / 2-65$.

${ }^{31}$ AJ, 498-57, Egipat.

32 AJ, fond 465, Savezni zavod za međunarodnu naučnu, prosvetno-kulturnu i tehničku saradnju, f. 1468 .
} 
objavljene su dve kratke priče u burmanskim časopisima. Nijedno obimnije književno delo nije bilo prevedeno i objavljeno. Slično je bilo i u suprotnom smeru. Ni u Jugoslaviji nije ništa važnije štampano od burmanskih knjiga. Pokušaji da se 1974. u Politici i Borbi objave kratke priče burmanske književnice Kin Mjo Čit (Khin Myo Chit) nisu uspeli. U burmanskim bibliotekama je bilo malo jugoslovenskih knjiga i one su bile političko-informativne. Da bi popravila takvo stanje, Ambasada Jugoslavije je 1975. tražila najpoznatija jugoslovenska književna dela na engleskom kako bi pokušala da pronađe privatne izdavače i renomirane prevodioce zainteresovane za njih. Podrazumevalo se da bi prevodioci morali da budu politički lojalni režimu. Sa njima je bilo moguće sklopiti dve vrste aranžmana: ili da se garantuje otkup jednog dela tiraža ili da se obezbedi hartija za štampanje u kojoj se u Burmi oskudevalo. ${ }^{33}$

Jugoslovenska književnost se do šezdesetih godina teško probijala na indijsko tržište. U Indiji je do tada prevedeno malo jugoslovenskih autora. Među njima su bili Andrić (Gospođica, na hindi, 1957), Cankar (Purana Naukar, hindi, 1956), Prešern (Slovene kabita (Slovenačke pesme), 1957, na bengali jezik) i Nušić (Wife of a Minister, 1961). Jugoslavija je prevela klasična indijska dela (Tagore). ${ }^{34}$ Bili su to skromni podaci ako se ima u vidu da su u Indiji 1964/65. štampana 32.622 dela. Doduše, polovina dela su bila na engleskom jeziku, a od indijskih jezičkih područja prednjačio je hindi jezik sa 2.376 naslova 1965/66. godine. Stvarni efekti proboja jugoslovenskih dela u Indiju nisu umanjivani samo njihovim malim brojem, već i malim tiražima knjiga na indijskim jezicima (najtiražnije knjige su izlazile u nekoliko hiljada primeraka), visokim cenama i malim procentom pismenosti u Indiji. Časopis Amrite Pritam, u kome su jugoslovenske pesme našle mesto i koja je bila najpredusretljivija za saradnju sa jugoslovenskim piscima, imao je samo 800 primeraka tiraža. Bili su to slabi efekti u zemlji od 550 miliona stanovnika i ostajali su uglavnom samo u uskim intelektualnim krugovima. ${ }^{35}$

O skoro potpunom uzajamnom nepoznavanju dve književnosti i kulture uopšte svedočila je i jugoslovenska kulturna delegacija koja je posetila Indiju od 16. marta do 13. aprila 1960. Prisustvo dva pisca (Blaže Koneski i Petar Leovec) bio je motiv da u svim gradovima u kojima je boravila jugoslovenska delegacija ima susrete sa piscima, shvativši da Indijci ,ne poznaju našu književnost i kulturu, kao što se kod nas ne poznaje indijska u dovoljnoj mjeri“" 36

Jugoslovenska diplomatija se, ipak, borila da privuče indijske pisce u Jugoslaviju. Tokom septembra 1960. Jugoslaviju je posetio indijski pisac Mulk Radž Anand (Mulk Rand Anand), čije su knjige već štampali „Zora“ i „Naprijed“" iz Zagreba. Ambasada u Indiji je preporučivala ovog pisca kao komunistu i vrlo uglednog javnog radnika. Da je želja jugoslovenskih predstavnika da

\footnotetext{
33 AJ, 465-1197, Burma.

${ }^{34}$ DA MSP, PA, 1963, Indija, f. 37, d. 17, 45953; AJ, 498, f. 32, 1961, Prepiska u vezi ostvarivanja međunarodne saradnje.

35 AJ, 498-39, Indija.

${ }^{36}$ DA MSP, PA, 1960, Indija, f. 39, d. 340/II, 419260.
} 
ga Jugoslavija ugosti imala dublje motive, pokazuje i opaska načelnika u DSIPu Draga Kunca 16. juna 1960: „Rusi se mnogo trude da ga drže uza se, međutim, on ima simpatije i za nas“. I indijski pisac Džajnendra Kumar (Jainendra Kumar) posetio je Jugoslaviju jula 1960. pošto mu je u Zagrebu već bilo objavljeno delo Resignation (preveo Čedomir Minderović). ${ }^{37}$ Mulk je u Jugoslaviji ponovo boravio od 18. do 22. jula 1970. Najviše vremena je proveo u društvu Mire Alečković. ${ }^{38}$

Ministar za kulturu i naučna istraživanja Indije Humajun Kabir (Humayun Kabir) posetio je jugoslovenski savez pisaca juna $1960 .^{39}$ Slovenački pisci Josip Vidmar i Jože Javoršek boravili su u Nju Delhiju 10-16. novembra 1961. za vreme proslave 100 godina od rođenja Tagore. Vesna Krmpotić je 1962. bila na studijskom boravku u Indiji. Književnica iz Indije Baldum Dingra (Baldum Dingra) posetila je jugoslovenski savez 29. maja 1963. i održala predavanje „Neki aspekti moderne indijske književnosti“ na Kolarčevom univerzitetu. ${ }^{40}$ Urednik indijskog tromesečnog časopisa National Integration, koji je izlazio u Nju Delhiju na engleskom jeziku, dr Gopal Sing (Gopal Singh) boravio je u leto 1965. u Jugoslaviji kao „ugledni javni radnik i član Gornjeg doma Parlamenta Indije“. Desetog juna se sastao sa Slavkom Mihalićem, Desankom Maksimović, Tanasijem Mladenovićem i Miodragom Pavlovićem. Posetio je Zagreb i Novi Sad, u kome je razgovarao sa piscima u redakciji Mađar so. ${ }^{41}$ Jula 1968. u Jugoslaviji su na Struškim večerima bili indijski pesnici P. Padmaradžu (Padmaraju) (telugu jezičko područje) i prof. Vasant Bapat (Vasant Bapat) (marati jezičko područje). ${ }^{42}$

Ovaj nivo saradnje nije zadovoljavao Jugoslaviju. Književna saradnja sa Indijom je imala određene specifičnosti, na koje su više puta upozoravale jugoslovenske diplomate u Indiji. Sekretar ambasade u Indiji Dušan Štrbac je preporučivao da se u odabiru pisaca koji će predstavljati Jugoslaviju u Indiji vodi računa ne samo o njihovom kvalitetu već i o tome da vladaju engleskim jezikom. Preporučljivo je bilo $\mathrm{i}$ da to budu pisci čija su dela već prevedena na engleski, jer bi se onda moglo razgovarati o prevođenju tih dela na neki od lokalnih jezika. ${ }^{43}$ Štrbac je insistirao da jugoslovenska strana u pregovorima o izdavanju dela jugoslovenske literature u Indiji izbegava zahteve za autorskim honorarom. Svaki takav zahtev bi mogao štampanje da odloži u nedogled. Bolje je bilo insistirati na obavezi izdavača da autoru dâ određen broj primeraka. ${ }^{44}$

U književnim odnosima sa Indijom bilo je neophodno voditi računa i o višejezičnosti te zemlje. Indijski ustav je priznavao kao ravnopravne 15 jezika, pored engleskog, te su indijske vlasti morale da vode računa o podjednakom

\footnotetext{
${ }^{37}$ DA MSP, PA, 1960, Indija, f. 39, d. 340/II, 417553; AJ, 498, f. 39, Indija.

${ }^{38} \mathrm{AJ}, 498-36$.

${ }^{39}$ AJ, 498-29, 626-561.

${ }^{40}$ AJ, 498-29, 626-561.

${ }^{41}$ AJ, 498-27, 1965, Pojedinačne posete savezu, Boravak dr Gopala Singha.

${ }^{42}$ DA MSP, PA, 1968, Indija, f. 49, d. 16, 423142; AJ, 498-39, Indija.

${ }^{43}$ AJ, 498-39, Indija, 205/1-68.

${ }^{44} \mathrm{AJ}, 498-39$, Indija.
} 
tretmanu svih jezika prilikom slanja pisaca van zemlje po programima kulturne saradnje. Jugosloveni su to ponekad gubili iz vida, pa je Ministarstvo prosvete Indije 1968. odbilo jugoslovenski predlog od 20. maja da Šiv Kumar Batalvi (Shiv Kumar Batalvi) dođe u Jugoslaviju na osnovu programa kulturne saradnje, jer nije želelo da nakon slanja prethodne godine Amrite Pritam, pesnikinje pendžabi jezičkog područja, ponovo pošalje pesnika istog područja, iako se radilo o piscu koji je pokazivao interesovanje za jugoslovensko stvaralaštvo (prevodio je Izlet $u$ nebo Grozdane Olujić). I jugoslovenska ambasada u Indiji je upozoravala da nije celishodno dve godine uzastopno pozivati pisca istog jezičkog područja, kao i da bi efekat upoznavanja sa jugoslovenskom kulturom bio umanjen time što je pendžabi jezikom govorilo samo oko 11 miliona stanovnika Indije. $^{45}$ Umesto njega u Jugoslaviji su, na osnovu predloga Ministarstva prosvete Indije, 1968. boravili pesnici P. Padmaraju (telugu jezičko područje) i prof. Vasant Bapat (marati jezičko područje). ${ }^{46}$

Od druge polovine šezdesetih godina jugoslovensko-indijska književna saradnja je bila sadržajnija i prevashodno vezana za nekoliko značajnih imena sa obe strane.

Za Jugoslaviju je od velikog značaja bio rad indijske književnice Amrite Pritam koja je 1967. posetila Jugoslaviju. Jugoslovenske državne vlasti su tražile od Saveza književnika da se prema njoj odnosi kao prema ,,izuzetnom gostu“. Letnje dane (11. avgust - 1. septembar 1967) provedene u Jugoslaviji iskoristila je za desetodnevno posećivanje Dubrovačkih letnjih igara, osmodnevni boravak na Struškim večerima poezije uz upoznavanje Ohrida, te za dvodnevno upoznavanje sa Beogradom i Kragujevcem tokom koga ju je Grozdana Olujić provela kroz umetničke galerije i groblje streljanih u Kragujevcu. ${ }^{47}$

Njen doprinos popularizaciji jugoslovenske pisane reči bio je veliki. Nekoliko brojeva svog časopisa na pendžabi jeziku Nagmani (Dragulj) posvetila je jugoslovenskoj literaturi. U junskom broju iz 1967. našle su se pesme Desanke Maksimović, Cirila Zlobeca, Janeza Menarta, Oskara Daviča, odlomak iz proze Crnjanskog i drugi tekstovi. U januarskom broju iz 1968. objavila je utiske iz Dubrovnika, Ohrida, Struge, Kragujevca i Beograda. Beogradski zapis je naslovila „Boemska ulica Beograda“ (oko „Tri šešira“ i „Dva jelena“), a „Kamena krila" je bio naslov teksta o Kragujevcu. I u tom broju je objavila nekoliko jugoslovenskih pesama. ${ }^{48} \mathrm{U}$ svoju antologiju Best Short Stories of the World uključila je i jugoslovenske pisce. Napisala je i knjigu sećanja posvećenu Jugoslaviji (Ruža s dvadeset jednom laticom) koja je 1972. štampana na hindu jeziku. Na pendžabi jezik je prevodila Desanku Maksimović, Tina Ujevića, Ivu Andrića, Cirila Zlobeca, Janeza Menarta, Vaska Popu, Dušana Matića, Oskara Daviča, Miodraga Pavlovića i druge pisce. U Jugoslaviji je 1977. objavljen njen

\footnotetext{
${ }^{45}$ DA MSP, PA, 1968, Indija, f. 49, d. 15, 412084; AJ, 498, f. 39, Indija, 122/2-68.

${ }^{46}$ DA MSP, PA, 1968, Indija, f. 49, d. 16, 423142; AJ, 498, f. 39, Indija.

${ }^{47}$ DA MSP, PA, 1967, Indija, f. 48, d. 13, 429058; AJ, 498, f. 57, Prepiska u vezi međunarodne saradnje sa prilozima; AJ, 498-37, Savezna komisija za kulturne veze sa inostranstvom, 439/1-67.

${ }^{48}$ AJ, 498-39, Indija.
} 
roman Taj čovek (prevela Grozdana Olujić). ${ }^{49}$ I pored tako plodne saradnje, bilo je potrebno da ona 1977. ugovori posetu Bugarskoj da bi je jugoslovenske vlasti pozvale da juna te godine posle Bugarske poseti i Jugoslaviju i to tek pošto je tu informaciju iz Indije donela Grozdana Olujić. Jula te godine obišla je Srbiju, BiH, Hrvatsku i Sloveniju. ${ }^{50}$

Dve države su ozbiljno pripremale dolazak indijskog pesnika na malajalam jeziku M. Govindana (Govindan) marta 1967. u Jugoslaviju. Do tada je njegov opus sadržao više knjiga - pripovedaka, eseja, drama. Bio je glavni urednik književnog i kulturnog časopisa na malajalam jeziku Sameeksha (Samikša, u prevodu Kritika). Bavio se i pozorišnom i filmskom umetnošću. Iz njegove molbe da mu se omogući da razmeni iskustva sa piscima Jugoslavije, upozna jugoslovenski teatar, film, dramu, slikarstvo i skulpturu, sazna nešto o prosveti i štampi u Jugoslaviji, obiđe neko poljoprivredno dobro, fabriku i ,neku drugu ustanovu koja bi mu pomogla da razume život i aktivnost naroda“, videla se želja za svestranim upoznavanjem jugoslovenskog društva. Vreme koje je proveo u Jugoslaviji (17. mart - 3. april 1967) bilo je vrlo bogato kulturnim i turističkim sadržajima. Boravio je na međunarodnom susretu pisaca „Ljudi od pera i turizam“ u Splitu (posetio Trogir, Solin i Hvaru). U Zagrebu, Ljubljani i Beogradu je razgovarao sa piscima i izdavačima, posetio Novi Sad, održao predavanje na indološkoj katedri u Zagrebu, obišao beogradske umetničke galerije. Prema svedočenju njegovih jugoslovenskih sagovornika, napustio je Jugoslaviju ,veoma impresioniran“ njenom stvarnošću. ${ }^{51}$

Sačidanand Hiranand Vatsjajan (Sachchidanand Hiranand Vatsyayan), pesnik, romansijer, izdavač i kritičar, poznat po književnom imenu Agjeja (Agyeya ili Neshvatljivo) bio je još jedna važna spona jugoslovenske i indijske kulture. Boravio je u Jugoslaviji više puta. U leto 1966. posetio je Beograd, Zagreb, Ljubljanu, Bled i Novi Sad. Njegov dolazak su jugoslovenski pisci iskoristili za pokretanje razgovora o prevođenju jugoslovenskih dela u Indiji. U severnoj pokrajini Srbije sreo se sa vojvođanskim piscima, razgledao Novi Sad i Galeriju Matice srpske. U Matici ga je primio sekretar Živan Milisavac. Dekan Filozofskog fakulteta Boško Novaković mu je priredio prijem na kome su bili predstavnici Katedre za engleski jezik i književnost, kao i pisci Aleksandar Tišma, Miroslav Egerić, Gojko Janjušević, Draško Ređep, Branko Momčilović i drugi. ${ }^{52}$ U vreme nove posete decembra 1968. u jugoslovensko-indijskim književnim odnosima bili su aktuelni prevođenje Andrićevih dela i izrada antologije jugoslovenske poezije na hindi jeziku koju je on pripremao. Jugosloveni su ga ugostili u Beogradu, Zagrebu, Sarajevu i Kruševcu čija je „Bagdala“" pripremala njegovu zbirku poezije. Sastao se sa Andrićem, pokušavajući da ubedi jugoslovenskog nobelovca da poseti Indiju. ${ }^{53}$

\footnotetext{
${ }^{49}$ AJ, 498-52, Br. 152.

${ }^{50}$ AJ, 498-52, Br. 152.

${ }^{51}$ DA MSP, PA, 1967, Indija, f. 48, d. 11, 47872; AJ, 498-39, Indija, 68/1-67; Isto, Indija, 156/1-67.

${ }^{52}$ AJ, 498-39, Indija, 486/1-66 i 434/1-66.

53 DA MSP, PA, 1967, Indija, f. 48, d. 18, 43273; AJ, 498-37, 321/1-68; AJ, 498-39, Indija, 230/1-68.
} 
Temelje svestranije književne saradnje sa Indijom udario je najviše Čedomir Minderović. Ostavio je dubok trag, a njegovo ime je i posle njegove smrti primano među indijskim piscima sa velikim pijetetom. Grozdana Olujić je 1967. konstatovala da je njegovo ime bila ulaznica za sva književna vrata Indije i dodala: „Čudan utisak da pokojni Minderović ne prestaje da pomaže na svakom koraku postaje sve jači. Zahvaljujući Minderoviću, u svakom jug. piscu Indijci vide prijatelja“. Dodala je da je on ugled jugoslovenskih pisaca u Indiji podigao „do neslućenog“" 54

Tamo gde je stao Minderović, Grozdana Olujić je nastavila posetama Indiji od 25. decembra 1966. do 24. januara 1967. i od 18. februara do 16. marta 1977. Prvi boravak u Indiji je imao uvertiru u vidu gostovanja pesnika i profesora Slamniga, čija su izlaganja o jugoslovenskoj modernoj poeziji dodatno skrenula pažnju indijskih pisaca na jugoslovensko stvaralaštvo. Pred njom su se tokom ove dve posete pružale lepote i umetnička dostignuća brojnih indijskih gradova kao što su Nju Delhi, Agra, Benares, Kajuraho (Khajuraho), Madras, Hajderabad (Hyderabad), Bombaj, Aurangabad, Džajpur (Jaipur), Čandigar (Chandigarh), Varanasi, Kalkuta. ${ }^{55}$ Nedovoljno razvijene književne veze uslovile su da na susretima sa brojnim sagovornicima u prvi plan stavi produbljivanje književne saradnje i uzajamno prevođenje. O tome je pričala sa dr Krišna Kripalaniijem (Krishna Kripalani) iz Sahitja Akademi (Sahitya Akademi ili Društvo književnika) i njegovim saradnicima. Neizostavan deo njenih boravaka u Aziji činili su susreti sa ljudima koji su već bili stari znanci jugoslovenskih pisaca. To su bili Amrita Pritam, ,koja je jedan od najboljih ambasadora naše kulture“ i koja je stranice svog časopisa rado ustupala jugoslovenskim piscima, Vatsjajan, koji je preveo i objavio brojne jugoslovenske pesme na hindi jeziku, kao i Andrićeva dela Prokletu avliju, Anikina vremena i Vezirovog slona, te pesnik Govindan, koji je ranije bio jugoslovenski gost i već objavljivao jugoslovenske pesme u svom časopisu Samekabe. Susrela se i sa profesorima i studentima na Delhijskom univerzitetu, sa piscima, dramatičarima i glumcima, urednikom značajnog časopisa Poetry of India Nisimom Ezekielom (Nissim Ezekiel) iz Bombaja, koji je već objavljivao jugoslovenske pesme, urednikom časopisa Kadambini, koji je u okviru izdavačke kuće „Hindustan Times“ objavljivan na hindi jeziku, piscem i urednikom izdavačke kuće „Chetna“ Surešom Kohlijem (Suresh Kohli). Brojnim sagovornicima je delila jugoslovenske knjige: Some Yugoslav Novelists, Few Notes about Yugoslav literature Today, Prokleta avlija, Big Mac Eriha Koša, Antology of Yugoslav Poetry, publikacije PEN kluba i druge.

Indijski književnici, naučnici, studenti i novinari su crpeli znanja o savremenim tokovima jugoslovenske literature iz niza predavanja koje je jugoslovenska pesnikinja održala. Tokom 1967. govorila je na seminaru na konferenciji o savremenoj poeziji u Jugoslaviji, održala više predavanja o jugoslovenskoj književnosti i recitovala jugoslovenske pesme piscima, novinarima i naučnicima na Univerzitetu u Benaresu (Benares University), Elphistons College u

\footnotetext{
${ }^{54}$ AJ, 498-39, Izveštaj o boravku Grozdane Olujić.

${ }^{55}$ AJ, 498-39, Br. 69/1-67.
} 
Bombaju i na Sahitja Akademi. Deset godina kasnije u Nju Delhiju je predavala o jugoslovenskoj zemlji i književnosti na Sahitja Akademi i na Kamala Nehru College, u Benaresu na Hindi univerzitetu, a u Bombaju na Bombajskom univerzitetu i u Mumbaj Marati Sahitja Sang (Mumbai Marathi Sahitya Sangh ili Savez književnika marati jezika u Mumbaju). U Madrasu je, uz predavanje o jugoslovenskoj literaturi, održala recital poezije jugoslovenskih pesnika prevedenih na engleski jezik (Desanka Maksimović, Vasko Popa, Dušan Matić). Na Osmanija univerzitetu (Osmania University) u Hajderabadu je, osim o jugoslovenskoj literaturi, predavala i o samoupravljanju studentima novinarstva. Prisustvujući 1967. „mušairi“ (pesnički recital) u Delhiju, na engleskom je čitala „Krvavu bajku“ Desanke Maksimović i „More“ Dušana Matića. Želja indijskih pisaca i vlasti da svoju zemlju što više približe jugoslovenskoj javnosti bila je vidljiva iz velikog broja istorijskih mesta i kulturnih ustanova koje je Grozdana Olujić imala priliku da vidi. U Agri je obišla Tadž Mahal (Taj Mahal), Fatehpur Sikri (Fatehpur Sikri), kompleks utvrđenja Crvena tvrđava (Red Fort ili na hindiju Lal Kila). U Benaresu je obilazila muzeje i hramove, Sanskrit univerzitet i razgledala manuskripte, a u Madrasu muzeje i videla najlepše hinduističke hramove Kančipuram (Kanchipuram) i Mahabalipuram (Mahabalipuram) u državi Tamil Nadu. U Kalkuti je stigla da obiđe Botanički vrt i hram boginje Kali i prisustvuje drami „Kralj tame“ od Rabindranata Tagore. U Bombaju je posetila muzej „Prince of Wales“. ${ }^{56}$

Njene posete Indiji su bile primer uspešne književne diplomatije. Brojni susreti, predavanja, razgovori, intervjui... širili su jugoslovensku pisanu reč u ovoj zemlji. Generalni konzul u Bombaju Živojin Bulat je, opisujući njen boravak u tom gradu 1967, pisao da je pesnikinja bila ,naprosto neumorna, te je sa jednog predavanja ili razgovora ulazila u drugi“, da su joj „njeno odlično poznavanje engleskog jezika, neusiljeno držanje, momentalni odgovori (duhoviti, nekad oštri, nekad puni humora, slobodni, a opet puni patriotizma) pribavljali poštovanje i predstavljali kao izvrsnog poznavaoca svoje struke“. ${ }^{57}$

Poseta Ivana Bratka Indiji od 20. februara do 21. marta 1968 (Bombaj, Kalkuta i Delhi) bila je mahom posvećena razgovorima sa najpoznatijim piscima i kontaktiranju izdavačkih kuća radi objavljivanja dela. Bratko se susreo sa najuglednijim indijskim pesnicima i piscima različitih političkih gledišta, umetničkih pravaca i generacija iz svih glavnih jezičkih područja. Pisci su ga primali u domovima ili $u$,živahnom društvu pesnika i pisaca istog jezičkog područja“. Indijce su interesovale književne prilike u Jugoslaviji, organizacija pisaca i odnos države i udruženja pisaca, kao i način na koji je Jugoslavija rešavala jezičko pitanje. Bratko je poneo pozitivne utiske o Indian Progressive Writers Association, organizaciji koja je postojala više od tri decenije. Razgovor sa Amritom Pritam je potvrdio njen veliki doprinos popularizaciji jugoslovenske književnosti u Indiji. U Nju Delhiju je razgovarao sa starijim piscem Džajnendra Kuma-

\footnotetext{
${ }^{56}$ DA MSP, PA, 1967, Indija, f. 48, d. 10, 44260; AJ, 498-39, Izveštaj o boravku Grozdane Olujić; AJ, 498-42, Izveštaj s puta u Indiji.

${ }^{57}$ DA MSP, PA, 1967, Indija, f. 48, d. 10, 45328.
} 
rom, čija je knjiga Rezignacija prevedena na srpskohrvatski. Bogat program je imao i u Bombaju. Posetio je pesnika na urdu jeziku Sardara Jafrija i pesnika Nisima Ezekiela, koji je izdavao časopis Poetry of India. U ovom gradu je bio gost Mulka Radž Ananda, koji je imao veliki međunarodni ugled i čija su dela čitana na dvadeset jezika. U Jugoslaviji su mu objavljeni romani Selo i Nedodirljivi. Većini indijskih kolega Bratko je ostavio dela jugoslovensku proze i poezije na engleskom jeziku. ${ }^{58}$

Bratko je uspostavio veze sa nizom izdavača. Jugoslovenska orijentacija je bila usmerena na srednje izdavače, kao i najveće (Asia Publishing House) koji su učestvovali na jugoslovenskim sajmovima knjiga. Ovom prilikom jugoslovenski pisac je uspostavio kontakte sa People's Publishing House u Nju Delhiju, Allied Publishers i Asia Publishing House u Bombaju. Tokom posete je razgovarano i o razmeni knjiga između nacionalnih i drugih biblioteka, a kao uzor su uzeti SAD, Britanija i SSSR koji su redovno snabdevali indijske biblioteke svojim izdanjima. Bratko je poneo niz knjiga indijskih autora koje su mu oni „spremno davali očekujući da će se nešto prevesti u Jugoslaviji“, ali su mu i skretali pažnju da bi dela indijskih pisaca u Jugoslaviji bilo bolje prevoditi sa originalnog jezika, a ne engleskih prevoda. U tom smislu veliki značaj u budućnosti trebalo je da odigraju studenti srpskohrvatskog jezika, koje je Bratko posetio na univerzitetu u Nju Delhiju. ${ }^{59}$

Jugoslovenski napori da svoju literaturu predstavi indijskim čitaocima, intenzivirani šezdesetih godina, nisu ostali bez rezultata, ali su i dalje bili ispod očekivanja. ${ }^{60}$ Ipak, iz godine u godinu Jugosloveni su postupno krčili put ka indijskoj publici, pa je do sredine sedamdesetih u Indiji objavljeno oko 75 knjiga jugoslovenskih autora ili knjiga u kojima su oni bili zastupljeni. Osim romana $N a$ Drini ćuprija Ive Andrića, koji je objavljen na svim jezicima Indije, publikovana su i druga Andrićeva dela (Anikina vremena, Vezirov slon, Most na Žepi i Prokleta avlija u prevodu Vatsjajana u knjizi objavljenoj 1974. na hindi jeziku), dela Grozdane Olujić, Ivana Cankara, Čedomira Minderovića, Branislava Nušića (Wife of Minister), Franca Prešerna, objavljeno je više knjiga ili časopisa sa delima jugoslovenskih pisaca. Amrita Pritam je objavila knjigu utisaka iz Jugoslavije Ruža s dvadeset jednom laticom. U knjizi Sticks of Fire objavljen je uvod Amrite Pritam o Jugoslaviji, te pesme Andrića, Zlobeca, Menarta, Daviča, Vaska Pope i prevodi pripovedaka Most na Žepi Andrića, Fratar $s$ zelenom bradom Vladana Desnice, tekst Seada Fatahagića i intervju sa Minderovićem. U časopisu Nagmani Amrita Pritam je više puta štampala pesme jugoslovenskih autora. ${ }^{61}$

Nesvrstana spoljna politika je obeležila socijalističku Jugoslaviju. Saradnja sa neangažovanim zemljama u svim sferama života predstavljala je jugoslovenski interes. Tu politiku je sledio i Savez književnika Jugoslavije, ali knji-

\footnotetext{
${ }^{58}$ DA MSP, PA, 1968, Indija, f. 49, d. 15, 42102; AJ, 498-39, Indija.

${ }^{59} \mathrm{AJ}, 498-39$, Indija.

${ }^{60}$ AJ, 498-39, Indija, Izveštaj za Komisiju za kulturne veze sa inostranstvom...

${ }^{61}$ AJ, 498-42, Izveštaj s puta u Indiji.
} 
ževne veze Jugoslavije i ovih zemalja nisu dostigle intenzitet saradnje u drugim oblastima. Uspostavljene su kasno i nisu bile redovne. Ipak, sa nekim državama je književna saradnja dala zapaženije rezultate, a bila je dobrim delom vezana za delatnost pojedinaca i trag koji su oni ostavili. Dobar primer su bili literarni odnosi Jugoslavije i Indije. U njihovoj saradnji su se isticali Čedomir Minderović i Grozdana Olujić sa jugoslovenske, te Amrita Pritam i Sačidanand Hiranand Vatsjajan sa indijske strane.

\section{REFERENCE}

- Bogetić Olivera, i Dragan Bogetić. Nastanak i razvoj pokreta nesvrstanosti. Beograd: Export press, 1981.

- Bogetić Dragan, i Ljubodrag Dimić. Beogradska konferencija nesvrstanih zemalja 1-6. septembra 1961: prilog istoriji Trećeg sveta. Beograd: Zavod za udžbenike, 2013.

- Bondžić, Dragomir. Misao bez pasoša: međunarodna saradnja Beogradskog univerziteta 1945-1960. Beograd: Institut za savremenu istoriju, 2011.

- Bondžić, Dragomir. „Stipendisti iz Indije i Burme u Jugoslaviji 1951-1955“. U: Spoljna politika Jugoslavije 1950-1961, Zbornik radova. Urednik Slobodan Selinić, 558-570. Beograd: INIS, 2008.

- Bondžić, Dragomir. „Studenti iz Alžira u Jugoslaviji 1958-1965“. U: Jugoslavija - Alžir. Zbornik radova sa naučne konferencije, Alžir 27. januar 2013. Glavni i odgovorni urednik Miladin Milošević, 141-162. Beograd: Arhiv Jugoslavije, 2013.

- Bondžić, Dragomir. „Školovanje studenata iz zemalja u razvoju kao deo spoljne politike Jugoslavije 1950-1961“. Annales. Anali za istrske in mediteranske študije. Series Historia et Sociologia, 24, 4, (Koper 2014), 637-648.

- Čavoški, Jovan. „Arming Nonalignment: Yugoslavia's Relations with Burma and the Cold War in Asia, 1950-1955“. CWIHP Working Paper, no. 61, Washington, DC: Woodrow Wilson Center, 2010.

- Čavoški, Jovan. „Ruka pružena preko sveta: jugoslovenska podrška Burmi u borbi protiv spoljne agresije 1952-1954“. Tokovi istorije, br. 2, (2018), 143-176.

- Čavoški Jovan, i Aleksandar Životić. „On the Road to Belgrade: Yugoslavia, Third World Neutrals and the Evolution of Global Non-Alignment, 19541961“. Journal of Cold War Studies, vol. 18, no. 4, (2016), 77-97.

- Dimić, Ljubodrag, Aleksandar Raković, i Miladin Milošević. Jugoslavija - Indonezija 1945-1967: istraživanja i dokumenta. Beograd: Arhiv Jugoslavije, 2014.

- Jugoslovensko-alžirski odnosi 1956-1979. Priredili Miladin Milošević i Nada Pantelić. Beograd: Arhiv Jugoslavije, 2014. 
SLOBODAN SELINIĆ, PhD, Senior Research Associate

Institute for Recent History of Serbia

Belgrade, Republic of Serbia

slobodanselinic@gmail.com

\author{
YUGOSLAV LITERARY SOCIETY \\ AND THE NON-ALIGNED COUNTRIES \\ FROM THE END OF 1950s TO THE BEGINNING OF 1980s
}

\begin{abstract}
Summary
The Non-aligned countries have always played an important part in $\mathrm{Yu}-$ goslav foreign policy, but the cooperation between Yugoslav and these countries' writers have been falling behind their collaboration in other fields. It was established much later, and its function was less effective, although Yugoslav Literary Society members were aware of the importance of a lucrative partnership with the non-aligned. Mostly during the seventies, Asian and African writers have been visiting literary conventions across Yugoslavia (Belgrade October Get-togethers, Poetry Nights in Struga, Literary Talks in Zagreb, Poetry Days in Sarajevo...). This was an important encouragement to the cooperation initiative. With some countries, collaboration was carried out even at a higher level which resulted in mutual visits and book translations. This was in particular the case with India. Especially prominent in this partnership were Čedomir Minderović and Grozdana Olujić of Yugoslavia, and Amrita Pritam and Sachchidanand Hiranand Vatsyayan of India.
\end{abstract}

KEYWORDS: Yugoslavia, Non-aligned Countries, literature, India, Egypt, Algeria 